\section{Ana Maria NARTI}

Baltagul lui Radu Penciulescu se străduiește să găsească în recompunerea scenică a dialogului şi a actiunii o cât mai supusă prezentare a creatiei care i-a folosit de izvor. Această fidelitate extremă, această subordonare programatică fałă de spiritul operei literare, are în momentul de fałă o însemnătate principială pentru teatrul nostru. Pentru că, indiferent dacă se adresează marilor balade populare sau dacă pleacă de la scrierile epice si lirice ale unor autori de primă mărime, textul spectacolului care caută să ajungă la sensurile mari ale traditiei legendare românești are nevoie de multă umilintă, de o deosebită vointă de supunere fată de metodele sale, atât de bogate. Altfel, este foarte uşor ca textul să alunece, cum s-a întâmplat şi în alte realizări, pe panta produsului artizanal, sclipitor şi găunos. Şi cum nu dispunem deocamdată de repertoriu bogat în acest domeniu, cum deci teatrul caresi va propune o asemenea montare va fi deseori obligat să-şi alcătuiască propria dramatizare, exemplul lui Radu Penciulescu se cuvine să fie refinut. El ilustrează o tendintă deosebit de importantă pentru noi, tendintă care caută în materialul literar si interpretativ întemeiat pe tradifia poporului, si a prelucrării culte de folclor nu aspectele superficiale, ci spiritul, climatul lăuntric, atmosfera afectivă şi de gândire care determină esential dinăuntru comuniunea artei moderne cu acumulări condensate în creatia poporului.

Ca toate piesele de acest fel, Tango are de câștigat din împletirea modalităfilor de interpretare care răspund în actiune caracterelor complementare ale partiturii. Penciulescu a realizat, cum arătam, această unitate a contrariilor înlănfuind înşelătoarele înfătişări ale firescului realist de suprafałă, pentru a le nega, mereu, prin amănuntul ireal, parcă desprins dintr-un cosmar. De aceea, detaliul - obiectul mărunt, gestul mic, intonatia de moment - si mai ales legătura violentă

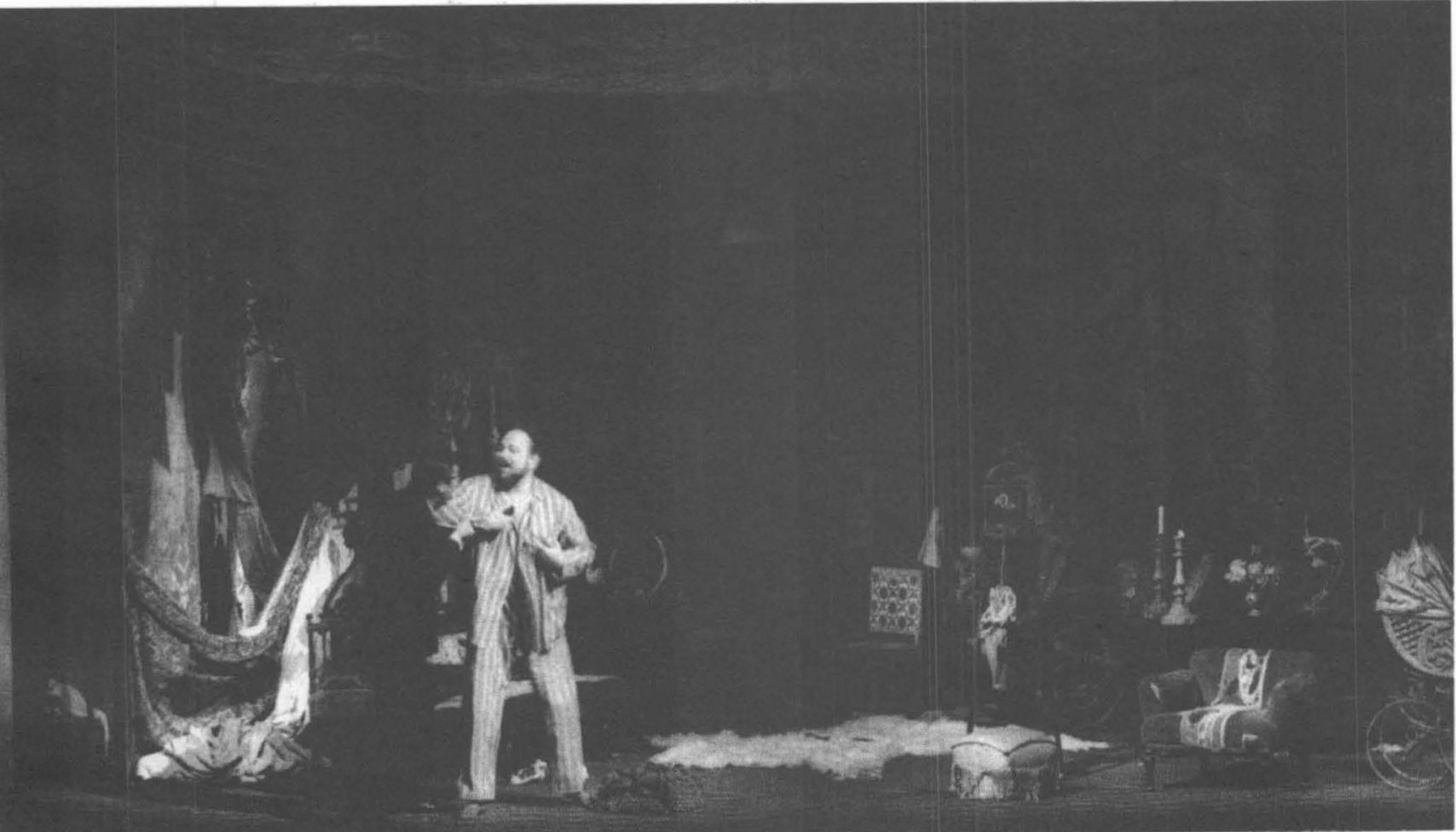


surprinzătoare, care se naşte între parte şi întreg, constituie motorul spectacolului, prin forta primă care supune și redescoperă textul în joc. [...]

Şi, în această privintă, regizorul a ales drept, pentru că într-o asemenea compozitie au însemnătate în primul rând nu concluziile - care se reduc la o teză demonstrată didactic, aproape matematic - ci, însăşi creșterea, desfăşurarea procesului reprezentat parabolic, trecerile, schimbările, prefacerile și devenirile care tes viata faptului real. Poate că de aceea regizorul s-a despărtit de acea pasiune a teatrului nud, care părea să-I stăpânească exclusiv până acum. El a simfit probabil că, reprezentat schematic, un asemenea text poate să moară, să se micşoreze până la teza uscată, pierzând tocmai acea multitudine de trimiteri corecte, care îi dă puterea de fascinatie. [...]

Această tragică și, din păcate, mult prea reală istorie contemporană, geometric expusă de Mrožek, capătă, în spectacolul de la Teatrul Mic, o claritate de ardere albă. Regizorul orchestrează atent acfiunile mărunte si mari, urmărind tot timpul împreună reactiiile celor sapte personaje. Studiul simultan de atitudini si manifestări intersectate începe şi se continuă mult timp ca o comedie - stranie, fără îndoială, si străbătută de tresărirea presimfirilor negre, dar plină de voiciune, strălucind nu o dată în reflexele jucăuşe ale unei veselii aproape copilărești. Nu este un efect accidental. Însăşi natura realitătilor evocate impune acest ton. Este vivisectia netulburatei "libertăti“ a intelectualului, închis, de fapt, iremediabil în temnifa de cuvinte sterpe pe care singur şi-a clădit-o. Această seninătate infantilă, lipsită de răspundere si amorală, este necesară în scenă, cu tot farmecul ei, pentru a explica puterea de seductie a noului conformism al nonconformismului. 